\title{
4
}

\section{Towards a More Diversified Supply of Welfare Services? Marketisation and the Local Governing of Nursing Homes in Scandinavian Countries}

\section{David Feltenius}

\section{Introduction}

Scandinavian countries are often believed to share a similar type of welfare state, one that is often referred to as the social democratic welfare model (Esping-Andersen 1990) or simply the Scandinavian model (Einhorn and Logue 2010). This type of welfare state is highly developed and covers an extensive range of social needs. Another common feature is that laws regulating social policy are universal in nature and target all citizens rather than specific groups (Anttonen 2002; Beland et al. 2014; Bergman and Strøm 2011; Burau and Vabo 2011). Accordingly, the model places a strong emphasis on equality in the sense that all citizens should be treated the same, regardless of where they live or their level of income (Kamp and Hvid 2012).

One of the dominant features of the development of the welfare state in Scandinavia in recent years can be summarised by the concept of

\footnotetext{
D. Feltenius $(\bowtie)$

Department of Political Science, Umeå University, Umeå, Sweden

e-mail: David.Feltenius@pol.umu.se

(C) The Author(s) 2017

K.H. Sivesind and J. Saglie (eds.), Promoting Active Citizenship,

DOI 10.1007/978-3-319-55381-8_4
} 
marketisation (Pierre 1995; Salamon 1993). This entails the establishment of a mix of different types of providers (public, nonprofit and for-profit) within welfare sectors, such as schools and elderly care (Ascoli and Ranci 2002; Blomqvist 2004; Feltenius and Wide 2015). Although this development has been similar across the Scandinavian countries, there are several differences in the sector that is our focus here; namely, nursing homes within the elderly care system.

The most evident difference is that a mix of different providers of nursing homes is more common at the local level in Sweden than it is in Denmark and Norway. In addition, Sweden has a larger share of for-profit providers and a more modest share of nonprofit providers than either Denmark or Norway (Dahler-Larsen 2015; Dølvik et al. 2015; Hartman 2011; Sivesind 2016).

The logic behind the establishment of this welfare mix is mainly to be found in the concept of new public management (NPM). There are many interpretations of what this concept actually stands for, but one key variable is governing through market-based mechanisms (Boston 2011; Dunleavy and Hood 1994; Ferlie 1996; Hood 1991; Pollitt 1995). Accordingly, the citizen is considered to be a customer in a market of different welfare providers. Allowing citizens to choose a certain provider over another in fields such as education, social services and health is believed to improve the quality of the welfare provision. This implies the exercise of 'active citizenship' through 'choice' of provider, whereby users can obtain services with a preferred profile. These concepts were presented in the first chapter of this book and will be further elaborated in Trætteberg's chapter, which compares consequences of different types of governance for the welfare service users' ability to control their own lives.

In order to establish alternatives among which citizens can choose, one might expect the growth of different profiles of nursing homes reflecting different types of providers. ${ }^{1}$ It has also been argued that privatisation allows for a more diversified supply of services than what public providers can offer (Ascoli and Ranci 2002; Weisbrod 1988). For instance, it is believed that nonprofit providers have a greater capacity to offer innovative and specialised services (Mariani and Cavenago 2013; Osborne 1998; Osborne 2010; Salamon and Abramson 1982). 
The argument that privatisation creates a more diversified supply of services is not universally accepted. In other types of care for the elderly - for example, home care services - it has been argued that there has been a 'decrease of choice despite the rhetoric of freedom of choice' (Dahl and Rasmussen 2012, 41). The cause of this paradox can be found in procedures of codification of care, which are a prerequisite for contracting out services. Codification of care refers to the specification of the amount of time devoted to, as well as the coding of, the performance of various tasks (Dahl and Rasmussen 2012, 41). In sum, this development implies greater local government steering, which leaves less room for the differentiation of services necessary to create different profiles of care.

Whether local government steering has in fact diminished, or whether the opposite is true, remains an open question, because very little is known about the local governing of nursing homes within the context of marketisation. Previous studies, at least in Sweden, have focused mainly on national laws directed at marketisation and elderly care (Erlandsson et al. 2013; Szebehely 2011). Considerably less attention has been devoted to the question of how municipalities handle their relationships with different types of welfare providers and what consequences this has for the profiling of welfare services. The work presented here seeks to address this topic.

Accordingly, the purpose of this chapter is to compare and explain similarities and differences in the service provision of nursing homes managed by different types of providers (public, for-profit and nonprofit) in six municipalities in Scandinavia. The primary focus of the comparisons is different types of providers. However, we will also explore differences between Scandinavian countries. The following research questions guided the study: Are there any differences between public and private (nonprofit or for-profit) providers with regard to developing a distinct profile of services? Are there any differences between the Scandinavian countries in this respect? To what extent can similarities and differences be explained by local governments' use of governing instruments? What are those instruments, and are they applied differently to public and private providers of care for the elderly? What is the rationale behind the use, or non-use, of those instruments? 
The argument of this chapter is that, contrary to what might be expected, there are no major differences between nursing homes managed by different types of providers. The similarity exhibited by different providers is a result of the fact that local authorities retain control of financing and regulation. In general, the regulations are detailed and make no distinctions between providers. This is evident from our empirical study of six Scandinavian municipalities. In these municipalities, interviews were conducted with politicians, administrators, managers and personnel at nursing homes. In some of the nursing homes, interviews were also conducted with residents. In addition, written documentation from nursing homes and public authorities (e.g., policy documents and evaluations) was examined.

This chapter is structured as follows. In section two, the theoretical framework of NPM is developed and a brief description of the research design is presented. In the third section, a brief discussion of care for the elderly in Scandinavian countries is presented. Sections four through six present the main empirical findings for Sweden, Norway and Denmark. In each section, the nursing homes and their activities are introduced, along with a presentation of the governing strategies performed by the municipalities. In the seventh section, we compare different types of welfare providers and draw conclusions regarding the service profiles of nursing homes and how such facilities are governed. In the final section of the chapter, the most significant findings are summarised and important questions for further research are discussed.

\section{Creating a Market for Elderly Care}

\section{Marketisation and New Public Management (NPM)}

Facing numerous challenges from the late-1970s onwards, welfare states have responded in many ways. One of these responses, particularly evident during the 1990s, is welfare retrenchment i.e. cutbacks in welfare spending (Pierson 1994; Lindbom 2001). Another response has been to reorganise the welfare state using the market as a model i.e. marketisation (Petersen and Hjelmar 2013; Pierre 1995; Salamon 1993). A theoretical 
account of this development is represented in the concept of New Public Management (NPM) (Boston 2011; Dunleavy and Hood 1994; Ferlie 1996; Hood 1991; Pollitt 1995).

NPM is an umbrella concept that covers different features of the organisation of the public sector based on the model of the market. These features include explicit standards and measures of performance, greater emphasis on output controls, disaggregation of units in the public sector, a private-sector management style and a shift to greater competition in the public sector. The emphasis on competition implies a greater role for contracts and tendering procedures (Hood 1991).

'Contracting' means that the delivery of services is delegated to private providers, while public authorities are responsible for regulation and financing. The public authority's choice of provider is the result of a tendering process in which different actors compete with each other on price or quality (Elinder and Jordahl 2013; Stolt and Winblad 2009). However, it is seldom the case that public authorities contract out all services within a given welfare field. A more common approach is delivering some part or parts of a particular service themselves while contracting out other parts. The result is a welfare mix of different providers, both public and private, which can be either for-profit or nonprofit.

\section{The Welfare Mix and Its Rationale}

The logic behind the establishment of this kind of welfare mix is that it allows for a more diversified supply of services in fields such as education, health and social welfare (Ascoli and Ranci 2002; Blomqvist and Rothstein 2000; Weisbrod 1988). Allowing for a more diversified supply is supposed to encourage the development of a broader catalogue of services compared to what public providers can offer on their own. It is believed that public service providers generally target the average citizen. The same is true for private, for-profit providers, who target the population that belongs to the largest segment of the market (Traetteberg and Sivesind 2015). However, this argument does not apply to nonprofit service providers. Quite the contrary, it has been argued that nonprofit providers have a greater capacity to offer innovative and specialised 
services (Mariani and Cavenago 2013; Osborne 1998; Osborne 2010; Salamon and Abramson 1982; Salamon 1987).

According to Lester M. Salamon, nonprofit service providers have several strengths, including a significant degree of flexibility in their operations. This results from the proximity of their governing boards to the field of action. Another major strength is the ability of nonprofit providers to offer greater diversity regarding the content of services. This is possible due to their small scale of operations, which allows them to tailor services to specific needs (Salamon 1987; Weisbrod 1977).

\section{User Choice}

One of the chief merits of a welfare mix is that citizens, who are referred to as 'customers', have alternatives from which to choose. Le Grand discussed the possibility of competition without choice and choice without competition (Le Grand 2007, 45). However, according to him, it is only when user choice is coupled with provider competition that the ends of a marketised welfare system are fully achieved. Le Grand considers this to be a case of governmental steering through 'the invisible hand'. Among the ends achieved by this type of steering are greater user autonomy, higher service quality and greater efficiency (Le Grand 2007).

Quality can be referred to in terms of both 'input' and 'output'. Input can be measured in relation to various parameters; for example, staff qualifications and expertise, class sizes in schools and the physical condition of buildings. The other aspect of quality, output, can be measured in terms of the results achieved by medical treatment or school attendance. Efficiency of welfare provision refers to achieving the highest quality and quantity from a given level of resources (Le Grand 2007).

However, it is important to note that the desired ends of 'choice' and 'marketisation' are not solely a matter of quality and efficiency. Another important end is the empowerment of citizens by making it possible for them to choose 'exit' in order to give them influence in welfare provision. Before marketisation, citizens could influence the provision of welfare foremost through 'voice', i.e. by expressing their opinions to decision- 
makers, either as individuals or as a collective body (Blomqvist and Rothstein 2000; Hirschman 1970).

\section{Governing Through Contracts}

Although customer choice is an important mechanism for achieving the aims of marketised welfare (i.e. improved quality and efficiency), it is far from the only one. Contracting out welfare services is a process regulated by national law and, in the field of elderly care, implemented by municipalities. A central feature of this process is that the municipalities stipulate the criteria that service providers must follow. This type of steering by municipalities is referred to as management by contract or governing through contracts (Almqvist 2001; Kamp and Hvid 2012, 40; Vabø 2007, 53; Walsh 1995).

The idea behind governing through contracts is that it makes it possible for public authorities to measure performance, which is a precondition for efficient service provision. In order to measure performance, the contract must be somewhat specific concerning the goals to be achieved (Vabø $2007,54)$. However, it has been pointed out in the literature that writing contracts for services is a difficult task because it is hard to identify objective standards. This is especially true in the field of care, due to the fact that it concerns the well-being of the elderly. Drawing conclusions concerning deterioration and improvement in quality as well as efficiency is a complicated matter (Almqvist 2001; Erlinder and Jordahl 2013; Walsh 1995, 52-53). One solution to the problem is to focus more on the methods that providers should use. However, this solution represents a deviation from the ideal, which is that the purchaser sets the targets and providers compete over how to achieve them using their best and most effective solutions (Almqvist 2001).

The ability to measure performance also requires establishing and implementing procedures for audits and inspections. This is considered to be particularly important in environments that provide services like care, where the providers usually have more information than the purchasers. Inspections can be carried out in many ways; for example, by responding to public complaints, conducting unannounced visits and 
examining random samples of work (Walsh 1995). The performance of these tasks requires a new kind of competence and administration at the level of the purchasing authority. It has been argued that the need for this type of administration eclipses some of the efficiency gains achieved by contracting out.

\section{Decreasing Choice_A Paradox}

From the discussion above, it follows that there are different mechanisms for reaching overall goals through the use of marketisation. These mechanisms have been referred to in terms of user choice and governing through contracts. Whether the mechanisms are compatible or not has been a topic of lively discussion. One issue that has received a significant amount of attention is the idea that marketisation actually creates a market of different providers with their own special profiles. It has been argued that customers actually have less choice and receive fewer individualised services than before-a condition that has been referred to as the 'decrease of choice despite the rhetoric of freedom of choice' (Dahl and Rasmussen 2012, 41).

To understand this argument, we will return to the practice of governing through contracts, which requires the codification of care. Without this, it would be difficult or nearly impossible to both write and evaluate contracts. By codification of care, we mean the specification of the time devoted to and the coding of the performance of various tasks. Completing such codified tasks is facilitated by the use of modern technology in home care services; for example, personal digital assistants. The overall result of this process, according to Hanne Dahl and Bente Rasmussen, is a growing standardisation of care (Dahl and Rasmussen 2012).

Standardisation of care represents a paradox in relation to arguments concerning the 'welfare mix' and 'customer choice'. This paradox has been clearly described by Dahl and Rasmussen, who argued that, contrary to what one would expect of marketised welfare, 'customers have less choice and receive fewer individualised services than they did in the old model where they were allotted time rather than tasks' (Dahl and Rasmussen 2012, 41). In the old model, the professionals, i.e. care 
workers, had a stronger position and a greater degree of flexibility in carrying out their tasks. It is argued that this environment gave the elderly more choices and thus more individualised service (Dahl 2009; Dahl and Rasmussen 2012, 41).

Based on the theoretical argument articulated by Dahl and Rasmussen, one might expect there to be no differences between public and private nursing homes due to the growing standardisation of the services carried out. However, their argument is built primarily on research related to home care services in Denmark. Whether this argument is also relevant in the context of nursing homes is an open question. It may be that governing in this particular activity is softer, thus leaving providers with greater room for providing a variety of services.

\section{The Empirical Study-A Brief Note}

In order to discuss the validity of the theoretical account of marketisation and expectations with regard to the profile of welfare services, an empirical study has been conducted. The study covers different types of welfare providers (public, nonprofit and for-profit) and their relations with municipal administrations in six municipalities: two in Sweden (Sollentuna and Östersund), two in Norway (Asker and Steinkjer) and two in Denmark (Faaborg-Midtfyn and Herning). In Sweden, two public and two for-profit nursing homes were scrutinised in greater detail. In Norway, two public, one for-profit and one nonprofit were investigated. In Denmark, the research focused on two public and two nonprofit nursing homes. The empirical investigation was carried out in 2013-2014 and followed a similar scheme in all countries. Considering the limited number of cases investigated in each country, the study is obviously only explorative but it nevertheless provides a point of departure for further research.

The empirical study consisted primarily of interviews with civil servants in the municipal administrations, politicians responsible for elderly care policy, and site managers at the nursing homes. ${ }^{2}$ A total of 20 interviews were conducted in Sweden, 19 (with 29 people) in Denmark and 26 (with 44 people) in Norway. The interviews were performed by 
different members of the research group. Each member was an expert on his or her country. A more elaborate presentation of how the empirical investigation was conducted can be found in the first chapter of this book and in the appendix covering the data collection and methods.

Managers at the municipal administrative unit responsible for care of the elderly are referred to as 'head managers of the administration'. Managers at the nursing homes are referred to as 'site managers'; it is also evident from the references in the text whether the unit is public, nonprofit or for-profit. Finally, interviews conducted with local politicians responsible for care of the elderly are simply referred to as 'politicians'.

In addition to the interviews, a variety of written documents were examined, including policy plans for care of the elderly, surveys, informational brochures about the nursing homes and party documents. This material was used to prepare for the interviews, as well as to triangulate information obtained from them. In the next section, the results of the investigation will be presented. We begin with a brief introduction of both the organisation of elderly care in Scandinavian countries and the municipalities chosen for this study.

\section{Organisation of Elderly Care}

\section{Responsibility of the Municipality}

In Scandinavian countries, care for the elderly is the responsibility of municipalities. In performing this task, municipalities are restricted by national laws only to a limited extent, because the relevant laws are 'framework laws' without detailed regulation. This is in accordance with the Scandinavian tradition of strong municipal self-rule (Gustafsson 1999, 52; Loughlin et al. 2011, 11). Municipal responsibility for care of the elderly includes both a financial and regulatory responsibility. It is the municipalities that interpret national laws and work out local guidelines for needs assessments. Thus, the decision to grant an elderly person home care services or a place at a nursing home is made by a care administrator following local guidelines for needs assessment. 
The overall balance between home care services and nursing homes for the elderly is also a matter for the municipality to decide. In recent decades, in all three countries, municipalities have started to give priority to home care services rather than offering elderly people a place at a nursing home (Hermansen and Gautun 2011; Hjemmehjælpskommisionen 2013). A natural consequence of this strategy is that the threshold to secure a place in a nursing home has risen (Gjevjon and Romøren 2010). In 2005, about $80 \%$ of those living in Norwegian nursing homes suffered from dementia (Haugen and Engedal 2005). Nursing home users, therefore, are in relatively poor health and make up only a fraction of the elderly who receive municipal services.

\section{Development of a Welfare Mix}

In all three countries, municipalities also have the authority to decide whether care for the elderly should be marketised. The municipality can decide that all services should be performed in-house or by a mix of public, for-profit and nonprofit actors. Denmark deviates in this respect because a national law from 2007 makes it possible for both nonprofit and for-profit actors to establish nursing homes irrespective of the wishes of the municipality (LBK 897)—so-called 'independent' nursing homes. ${ }^{3}$ Most of the independent nursing homes that have been created since the law came into effect are run on a nonprofit basis (Rambøll 2012, 15).

The most rapid development towards marketisation has taken place in Sweden's 290 municipalities (Jordahl and Öhrvall 2013). In 1999, 54 municipalities had private providers of nursing homes. This figure had risen to about 93 by 2016 (Socialstyrelsen 2004, 2017). ${ }^{4}$ These are mainly for-profit companies because nonprofit organisations play a very limited role in Sweden (Erlandsson et al. 2013; Stolt and Winblad 2009).

In Denmark, nonprofit providers play a more important role than their for-profit counterparts, although the overall development of the privatisation of nursing homes has been modest (Bertelsen and Rostgaard 2013). The development of privatisation has also been modest in Norway, although most non-municipally operated nursing homes are run by for-profit care companies. According to figures from 2010, about 
70 Norwegian nursing homes are managed by civil society organisations, such as foundations or voluntary organisations (Vabø et al. 2013).

In sum, it is evident from this section that the organisation of care for the elderly is similar in Scandinavian countries. It is the municipalities that have the overall responsibility for this task and can decide the type of welfare provider. In the next three sections, the results of the empirical investigation will be presented for each of the three countries. Each section begins with a presentation of the nursing homes that were investigated. This is followed by a deeper examination of the issue of how municipalities govern nursing homes for the elderly.

\section{Sweden}

\section{Nursing Homes and Their Profiles}

In both Swedish municipalities, the welfare mix consists of public and for-profit providers. In Östersund, most of the nursing homes are operated by the municipality's provider. The situation is the opposite in Sollentuna, which has only a few public nursing homes. These are run by Sollentuna Omsorg (SOLOM AB), which is owned by the municipality.

In both municipalities, private providers consist of nationwide, for-profit companies such as Vardaga, Attendo, Förenade Care and Aleris. In addition, there are smaller for-profit companies in both municipalities; for example, Vårdstyrkan $\mathrm{AB}$ and Strukturrutan. In Östersund, contracting out has been deliberately organised in a way that facilitates the participation of smaller companies.

Two nursing homes per municipality were scrutinised in detail: one private (in both municipalities, one of the homes owned by a nationwide company) and one public. The four nursing homes were similar in terms of the number of beds and clients. They were also similar with regard to the physical and mental (dementia) diagnoses of the clients. To determine whether there were differences among the nursing homes, interviews were conducted with site managers, politicians and administrators. In addition, relevant documents were examined; for example, informational brochures, websites and annual reports. 
From the interviews, it appears that there is no clear profile among the investigated nursing homes. Instead, special competencies among the staff or the implementation of particular projects were mentioned. For instance, at one of the private homes, one nurse is a 'Silvia-nurse', a title one earns by attending a special training programme that emphasises care for elderly persons with dementia (Interview, site manager, private, 2014-02-05). Another example, from the other private nursing home, is a project involving putting pets in the care facility in order to promote well-being among the elderly (Interview, site manager, private, 2014-04-14).

Particular projects like these can also be found at the public nursing homes. For instance, cooperation with civil society was mentioned in the interviews. The local branch of the Red Cross visits nursing homes and offers activities for the elderly such as 'sing-alongs' or reading aloud (Interview, site manager, public, 2014-04-14). However, none of these projects are undertaken with the aim of giving the nursing home a distinct profile. In one of the public nursing homes, the site manager explained that the elderly are often in poor physical and/or mental health and are thus not vigorous enough to participate in different activities: 'You don't move here because you are interested in gardening or anything else' (Interview, site manager, public, 2014-02-14).

This statement reveals something important about the situation at nursing homes in Sweden today. Elderly persons are given places at nursing homes only when they are seriously ill and cannot manage on their own without assistance from home care providers. One manager claimed that once you move into a nursing home, it is probably the last place you will live in your life. This fact needs to be considered when discussing 'choice' and a 'diversified supply of services'.

Rather than referring to differences, site managers at nursing homes emphasise similarities. One of the similarities is working with a municipal programme about basic values within elderly care. This programme is the municipality's interpretation of the national basic values outlined in the Social Services Act. At each nursing home, regardless of provider, there is a member of staff who is responsible for implementation. In Östersund, the basic values have been interpreted as guarantees for the elderly. First, each elderly person is guaranteed a contact person 
responsible for ensuring that communication among the resident, relatives and staff functions satisfactorily. Second, an individual implementation plan must be drawn up, with information about how and when care is to be performed. Third, care must be provided at a time upon which the parties agree (Östersunds kommun 2014).

The individual implementation plan (i.e. care plan) is a central feature of care at all nursing homes. ${ }^{5}$ Its purpose is to ensure that care is planned on the basis of the particular needs of the individual. Upon arrival, the elderly and their relatives meet with the nursing home staff. The staff provide information about daily routines and what to expect in terms of activities. The elderly and their relatives explain their expectations of the nursing home. The elderly resident is asked questions, such as 'What food do you like to eat for breakfast?' 'What clothes do you prefer?' 'Do you have different preferences on weekdays as opposed to weekends?' All the information is recorded in an implementation plan that is then accessible to the staff at the nursing home (Interview, site manager, public, 2014-04-14).

The aim of this procedure of drawing up individual plans is to provide an opportunity for the elderly to influence the care they receive and how it is performed. At one of the private nursing homes, the manager explained that this procedure represents an important development over time, in which the focus of user influence has shifted from 'users as a collective' to 'users as individuals' (Interview, site manager, private, 2014-04-14).

Given the similarities among the nursing homes we investigated, it is not surprising that elderly residents and/or their relatives rate the quality of care as equivalent. In Sollentuna, a quality survey was carried out in 2012. It measured a range of variables such as safety, social interaction, self-determination and integrity. An index comprised of all variables revealed only negligible differences between the two nursing homes we studied. The private home had a slightly better score (Sollentuna kommun 2012). In Östersund, however, the public provider received a slightly better score in a survey from 2013.

On a question concerning overall satisfaction, the public nursing home received an average value of 8.8 out of 10 (response rate, 63\%) (Östersunds kommun 2013-06-13), while the private home received a 
value of 6.5 (response rate, 50\%) (Östersunds kommun 2013-09-16). According to statements made in the survey's open-answer section, one possible explanation for this difference is that the private nursing home is located in an old building, while the municipal nursing home is located in a relatively new building.

\section{Governing of Nursing Homes}

It is evident from the interviews that the similarities among the nursing homes can primarily be explained by the way the municipality steers elderly care. While national guidelines and laws also play an important role in determining the services provided, the focus here is on municipal (local) governance of nursing homes. One governing instrument are long-term plans for elderly care. For instance, in 2006, the Östersund council adopted a plan with multiple goals, including accessibility, influence, culture and competence among staff (Östersunds kommun 2006). Sollentuna has a similar policy document containing key areas identified as subjects of special attention. Among them are elderly people's influence and independence, safety and active lifestyle (Vård-och omsorgsnämnden 2013).

Another type of governing instrument, or perhaps more of an underlying precondition, is the procedure for choosing a nursing home. Municipal care administrators decide whether an elderly person qualifies for a place at a nursing home. If so, he or she has the right to express a preference for a particular facility. However, this preference is not always easy to accommodate, because there are a limited number of rooms available at each nursing home. When a room becomes available, it is reported to the municipal administration, which passes the information on to the elderly person. Since people who are waiting for a space in a nursing home are generally in poor health, they typically accept the room that is offered, regardless of whether it is their first-choice (Interview, head manager, administration, 2013-12-13). That the system operates this way also impacts the incentives that providers of nursing homes have for developing different profiles. Since elderly persons are placed at a particular nursing home, the homes do not need to 'attract customers on 
a market'. In reality, the market is very limited (if not non-existent), since the ability of an elderly person to make an active choice is very restricted for both medical and capacity reasons.

Another type of instrument are contracts between the municipality and the nursing homes. In the case of contracting out, a contract is signed with the provider that submits the winning bid. In Östersund, the contract is awarded to the provider who can manage the nursing home in accordance with criteria specified in a tendering document at the lowest price. Sollentuna applies a different model, in which the sum received for operating the nursing home is fixed. The provider who can offer the best quality at the sum offered gets the contract.

The contract contains the criteria from the tendering documents as well as additional criteria, which makes it an important steering document for the municipality. For instance, it may include criteria about staff competence, safety, nutrition or influence for the elderly resident. If, during the tendering process, the providers promised to deliver other measures of quality - for example, staff with particular competencesthen this is also included in the contract. Although public providers do not participate in the tendering process, their operations are also regulated in a contract of this type.

In Sollentuna, governing through contracts applies both to private and public nursing home providers. The public provider gets no special treatment. One head manager of the municipal administration said that every provider should be treated the same, regardless of whether they are private or public. This is motivated on the grounds that elderly care is offered in a competitive market. In reality, there are some differences due to the fact that contracts are written at different times. Nonetheless, the overall ambition of the municipal administration is to treat all providers the same (Interview, head manager, administration, 2013-12-13).

The head of elderly care administration in Sollentuna holds the view that the use of the contract implies rather hard steering of nursing homes. The municipality has many conditional requirements, which are included in all contracts, which suggests that services are largely the same, regardless of provider. In addition, this has implications for the possibility of choice for the elderly. Simply put, there is not much to choose from because there is little difference among nursing homes (Interview, 
head manager, administration, 2013-12-13). Politicians share this view. Therefore, one ambition for the future is that the conditional requirements focus more on what is to be done and less on how it should be done (Interview, conservative politician, 2013-12-11).

Managers of nursing homes in Sollentuna stress the importance of local guidelines, national guidelines and laws, and contracts with the municipality. The contract is seen as rather detailed, including, for example, guidelines for meals and the maintenance of the facilities. There are even instructions about financial responsibility if washing machines break down (Interview, site manager, public, 2014-02-14; site manager, private, 2014-04-14).

The situation is similar in Östersund. Every provider, regardless of whether they are private or public, must follow a number of quality criteria. These criteria are listed as conditional requirements in the contract with the nursing home provider. The implementation of the criteria ensures that the services provided at the nursing home are similar. Private nursing homes also have to follow an additional quality programme formulated by the company. Despite the fact that the operation of the private nursing home is governed from many different directions, the manager believes that there is some freedom to decide how to deliver the requested service (Interview, site manager, private 2014-04-14). At public nursing homes, the existence of quality criteria is mentioned alongside the budget provided for their operation (Interview, site manager, public, 2014-04-14).

In both municipalities, public administrators closely monitor nursing homes to ensure that they abide by their contracts. In Östersund, one of the politicians mentioned that the contracts and their criteria are not worth much if the homes are not monitored to ensure compliance (Interview, social democratic politician, 2014-04-07). Therefore, a special division within the administration conducts an annual follow-up of the nursing homes. It is conducted using a point system in which different scores require the home to undertake specific types of action. The procedure is carried out at both public and private nursing homes; everyone is treated the same (Interview, head manager, administration, 2014-04-07). 
In Sollentuna, the monitoring of nursing homes takes place prior to the renewal of a contract. If the provider does not fulfil the criteria first agreed upon, then the contract may not be extended. This is not an empty threat because it has actually occurred. Instead of renewing a contract, a facility can be taken over by a municipal company (Interview, head manager, administration, 2013-12-13). A representative from the opposition party holds the view that this type of monitoring is insufficient, and that there is a need for more regular inspections both early on and in the middle of a contract period (Interview, social democratic politician, 2014-01-15).

In terms of future developments, the head manager of the elderly care administration in Östersund argues that one important task involves closely evaluating and scrutinising the criteria used. There might be some criteria that unnecessarily constrain operations (Interview, head manager, administration, 2014-04-07). Politicians have different views about the need to loosen up the governing of nursing homes in order to allow for greater variation in service supply. The politician representing the Centre Party wanted to see greater variation in the future, while the representative of the Social Democratic Party was more interested in a different goal. This representative argued that the purpose of having a mix of welfare providers is to be able to compare. How much does it cost to engage in an activity with a certain level of quality? What does a private operator cost in relation to a public operator? (Interview, social democratic politician, 2014-04-07).

The argument above illustrates the fact that politicians might support contracting out for different reasons. It is not necessarily about empowering the elderly and giving them a range of welfare providers with different profiles to choose from. Another motive might be formulated in terms of benchmarking, i.e. helping the municipality establish some point of reference about the cost of the elderly care provision.

In sum, evidence from the Swedish case suggests that there are no major differences between providers with regard to the services provided. This is explained by the fact that municipalities exercise hard rather than soft governing of nursing homes. Even though public providers do not participate in the tendering process, they are subject to the same steering as private providers. The rationale for this is that all providers should be 
treated the same by the municipal administration. In the next section, we use the same research questions to analyse the case of Norway.

\section{Norway}

\section{Nursing Homes and Their Profiles}

In the Norwegian case (the municipalities of Asker and Steinkjer), the welfare mix consists of public, for-profit and nonprofit nursing homes. Representatives from both for-profit and nonprofit nursing homes claim that they are distinct from their public counterparts. The for-profit nursing home refers to a particular 'service concept' that the company developed in its hotel management operations and subsequently introduced to nursing homes. The company has lauded its concept in its communication with both users and the municipality (Interview, site manager, for-profit, 2013-11-11).

Interestingly, neither users, staff or the municipality identified service as a special trait of this nursing home. Moreover, in the latest user survey, the for-profit nursing home had the lowest score on all service measures. When specifically asked what is uniquely special about the nursing home, the staff did not mention the service concept, which casts doubt on its importance. The elderly residents experience their nursing home through their interactions with care providers. If these providers are unaware of a concept, it cannot be seen as a defining trait of the home.

The nonprofit nursing home in this study has a diaconal approach to its operations; thus, according to the site manager, Christian values are a subject that is discussed when prospective staff are interviewed (Interview, site manager, nonprofit, 2014-01-27). Nevertheless, the municipality and elderly residents do not think that the diaconal approach influences care in important, substantive ways. As the administrative head at the municipality claimed, 'No, I don't think they have more visits from the priest and "stuff like that" than the other nursing homes' (Interview, head manager, administration, 2014-02-20).

In both municipalities, the interviewees from the municipal administration stressed that there are no differences between public and 
nonpublic nursing homes, and that no differences are indeed desired. All citizens have the same right to services, and the municipality allocates citizens to providers. Accordingly, from the point of view of the municipality, it is not possible to defend any difference in the content of the service provided. An elderly person can say that he or she prefers to live at a particular nursing home; but, in reality, capacity limitations will force him or her to take the first available slot. When an elderly person's health has deteriorated to the point of earning placement in a nursing home, then it is not usually possible to wait for a place in a preferred home to open up. Representatives of elderly residents of nursing homes stated that when someone prefers a particular home, the most important reasons for this preference are geography and proximity to a former home or where their relatives currently live. Some also mentioned general perceptions that a particular home has a reputation for offering high-quality service, but such perceptions are based on the anecdotal experiences of friends and families. Substantive differences among the nursing homes are not given as a prominent explanation.

In Asker, the municipality contracted the for-profit provider through a public tender in order to reap benefits from the tender itself. The tender provides a benchmark for how nursing homes should be run, something that the municipality can subsequently use in its steering of municipal nursing homes. The political and administrative leaders in the municipality as well as the head of the municipal nursing home alleges that the for-profit nursing home serves as a benchmark for public institutions. In addition, the municipality prefers to see some innovation in the form of differences in the administration and organisation of the private nursing home. However, elderly residents do not experience these differences as substantive differences in care.

In Steinkjer, the municipality does not want the nonprofit nursing home to be different from its public counterpart. On the contrary, the municipality wants it to operate largely the same as public nursing homes. In this sense, public nursing homes act as benchmarks for the nonprofit home. The municipality has a geographically dispersed population, and the geographic dimension trumps the issue of the type of welfare provider. At the same time, the interviewed actors were aware of the fact that the nonprofit nursing home is not part of the public 
hierarchy, and they were committed to ensuring that the municipality did not treat it as inferior.

The only tool for systematically comparing the nursing homes in the municipalities on objective quality indicators is the user survey carried out annually in Asker and twice a year in Steinkjer. Given the poor health of the residents, there were a number of methodological challenges involved in conducting the surveys. Nonetheless, the results consistently showed that there are no systematic differences between nonpublic and public nursing homes. The variation in results that did occur was not due to variation in the type of provider-i.e. public or private.

\section{Governing of Nursing Homes}

To understand the limited difference between public and nonpublic nursing homes, it is necessary to examine how the municipalities carry out local governance. National laws and regulations are the same for all providers, but differences across municipalities reveal the opportunities that municipalities have to influence the institutions for which they are responsible. Municipalities might exploit the opportunity available for local adaptation in order to allow for differences among various actors in the welfare mix. However, as discussed above, the interviews show that municipalities do not want differences.

The contracts that the municipalities have with private nursing homes govern their regulation. The nature of the contracts in Asker, which has a for-profit provider, and Steinkjer, which has a nonprofit, are different. Turning first to Asker, the contract is detailed with respect to a number of aspects of care to be provided. In the view of the head of the nursing home, 'I think that we are not completely private. The municipality sets the standard and is responsible for the care' (Interview, site manager, for-profit, 2013-11-13). This comment illustrates the fact that both parties find public control and intervention in the provision of services to be natural. However, the contractual relationship between the municipality and the for-profit home means that it is not natural for the municipality to intervene in the daily operations of the nursing home. With regard to the public nursing home, it has a frame budget and, in its 
experience, a certain amount of leeway for developing a particular profile. For example, one public nursing home has special expertise on severe dementia. The development of this profile was the result of an initiative at the nursing home itself. In this way, both public and for-profit nursing homes have some leeway to carve out profiles, but the resulting differences stem from factors other than the type of provider.

The contractual relationship between Steinkjer and its nonprofit home is different. The contract is less detailed in terms of content of care, but it does include a number of passages that force the provider to adapt to municipal standards and, crucially, entitles the municipality to intervene on a detailed level in the operation of the nursing home. The municipality could have opted for a hands-off approach; but in reality, the municipality is interested in detailed issues that go beyond care-related matters. For example, the municipality is involved in the number of people working in the administration of the nursing home as well as the wages of managers at the institution. The head manager of the municipal administration described a close relationship with a continuous discussion about detailed aspects of care. She concluded:

The feedback [from the nonprofit nursing home] is that they think it is all right that we exercise oversight over the professional standards of care and that we are concerned that the product we pay for maintains a high standard, in the best interest of the citizens of Steinkjer. And they want to deliver a product that makes us willing to continue to use them. I have not experienced any conflict about this. (Interview, head manager, administration, 2014-02-20)

In spite of the fact that the for-profit nursing home has a more detailed contract, it seems as if it has more room to manoeuvre than its nonprofit counterpart. The contract of the for-profit facility shields it from certain forms of intervention by the municipality in matters that are not regulated in the contract. For example, while a cut in public spending on nursing homes would not affect the for-profit nursing home during the contract period, the nonprofit nursing home would be affected in the same way as the municipal ones. The larger the share of nursing home places located in for-profit nursing homes, the more severe the cuts on public institutions. 
The municipal nursing homes in both municipalities are integrated into the municipal structure. This means that, formally, municipal politicians and administration can intervene in the institutions at any time. In reality, this occurs on issues such as the structure of care places. As the administrative head of Asker, which has the for-profit provider, explained:

When I speak about dimensioning, it concerns the number of short-term and long-term places. It is important that this is dimensioned correctly [...] With municipal provision, I can make the change like this [snaps her fingers], immediately, but I cannot do that if it is on a contract. Then it is a longer process. (Interview, head manager, administration, 2013-11-19)

What this comment illustrates is that it is easier to force changes on municipal nursing homes than non-municipal ones. When it comes to issues relating to the content of care, however, things are different. Professionals at the nursing homes make decisions on these matters. For example, public homes for elderly care have tested alternative schedules for work shifts and the use of dogs to stimulate residents, all without consulting municipal authorities in advance. The central point is that the tools that municipalities use to govern nursing homes are different depending on whether the home is public or private, but the effect is more a matter of administrative differences than the content of care.

Within each municipality, each of the nursing homes reported the same indicators to municipal authorities in order to facilitate comparisons among them. Some of these indicators include staff sick leave, financial matters, changes in the educational composition of the staff, and other issues regulated in the contracts. The user surveys administered by the municipalities are the most important instrument for comparing the nursing homes. The surveys are the same for all homes, and they receive considerable attention from politicians and the municipal administration. Any nursing home, public or nonpublic, whose results are unsatisfactory is summoned to a meeting in order to explain the results and draw up plans for improving them. Since the survey is the same for all nursing homes, it provides an incentive for all of them to work on the areas raised in the surveys, because they know that these are the issues on which they will be measured and evaluated. 
In Steinkjer, the governance model of elderly care is well established and no changes are imminent. This is a large, rural municipality, and ongoing debate about whether to centralise or maintain a broad range of services in all communities within the municipality has occurred as a result. Steinkjer's nonprofit nursing home is located on the outskirts of the municipality, and might therefore be vulnerable. Despite this, it has considerable political support, and both strategic plans and interviewees we spoke with agreed that major changes are unlikely.

In Asker, the municipality is currently preparing a new tender and its for-profit company must compete to retain its contract. According to both political and administrative leaders in the municipality, the price is not likely to be an evaluation criterion in the tender. According to the head of elderly care in the municipality:

I do not think there is as much to gain from competition as there was earlier. The municipality has worked a lot on efficiency and closed the gap on average expenses compared to a few years ago. That is my experience, and that is why it is interesting to compete on quality, to see if the private sector can do it for the same price, but with better quality (Interview, head manager, administration, 2013-11-19).

Such a shift in strategy on the part of the municipality would invite private providers to offer additional areas that can be included in the contract. It also reveals an ambition on the part of the municipality to find private providers that deviate more from public nursing homes in their operations. However, the municipality has no plans to change the way it steers in order to obtain differentiation.

In conclusion, the evidence from Norway implies that there are no important differences in the content of care due to a nursing home being public or private. The explanation for this is partly that there is little room to deviate from the municipal standard within the municipal governance regime. A municipality can either use a detailed contract to impose its standard - as is the case for Asker's for-profit nursing homeor it can intervene more directly in the operation of a nursing home, as in the nonprofit case in Steinkjer. The greater the number of quality 
indicators, like user surveys, that the municipalities use, the stronger the convergence in how nursing homes operate.

\section{Denmark}

\section{Nursing Homes and Their Profiles}

Four nursing homes in two municipalities (Faaborg-Midtfyn and Herning) were examined-two public and two nonprofit. Both nonprofit nursing homes have a Christian profile and belong to the large nonprofit organisation, Danske Diakonhjem, which runs about 50 nursing homes in Denmark (www.danskediakonhjem.dk). Both of these homes have contracts with their local municipalities.

In the Faaborg-Midtfyn municipality, the municipal website makes no distinction between the nonprofit nursing home and the public nursing homes. This is in contrast to the situation in Herning, where a clear distinction is made between different types of nursing homes on the municipality's website. Moreover, the situation in Herning is different from the situation in Faaborg-Midtfyn, as the former includes two independent nursing homes. Both of these homes were established as a consequence of a municipal decision to cancel contracts with nonprofit nursing homes. The independent nursing homes were not closely examined in the empirical analysis presented here, but they played an important role in the interviews that were conducted with municipal actors. In addition, a single interview was conducted with the manager of one of the independent care homes in order to attain an overall understanding of their special status.

All four nursing homes have the same general principles for care, which focus on adapting care services as much as possible to accommodate personal needs and resources. The homes also strive to make the facilities homelike, and thus to involve the elderly in the daily life of the nursing home as much as possible. For instance, they have kitchens that allow elderly residents to participate in cooking activities. Not all nursing homes in the investigated municipalities have kitchens, but the ones selected for this study do in order to ensure that they all shared similar 
characteristics. The four homes are also of similar size. Three of the four are situated in small towns, and one is located in an urban area. In each of the nursing homes, interviews were conducted with managers, employees and representatives of user boards, primarily relatives of elderly persons living at the homes. None of the municipalities in the study administers user surveys on a regular basis, and no comparable surveys were available.

From the interviews, it is evident that there are no major differences between public and nonprofit providers with regard to the content of care. In all four nursing homes, great emphasis is placed on implementing homelike principles of care, as was mentioned above. However, the implementation of these principles is limited by the physical and mental condition of the elderly, as well as by the limited resources of the nursing homes (Interviews, employees, municipal nursing home, 2014-03-06). The weak condition of the elderly at the nursing homes is also important to keep in mind when considering the scope for freedom of choice. Although there is freedom of choice, it can in practice be limited by room availability combined with the urgency of care.

Some of the relatives in the interviews claimed that they were not able to wait for a vacant room at their first-choice home; therefore, they accepted the first available room. According to nursing home managers, while residents seldom move to a different facility, it does sometimes happen when an elderly person did not originally get their first-choice (Interview, manager, municipal nursing home, 2014-01-10). The interviews also reveal that the most important factor for choosing a nursing home is related more to geographical location and less to other characteristics of the homes:

I think geography is the main reason. I wish I could say that it is because of us, but it is not. Of course people from the area want to stay here, because it is here that they have their social circles and their children. (Interview, manager, nonprofit nursing home, 2014-02-20)

Among the relatives we interviewed, it is also evident that the distinctive Christian profile is not the main reason why people choose nonprofit nursing homes. Again, geography and good reputation are mentioned as 
the main reasons (Interviews, user boards, nonprofit nursing home, 2014-03-12). However, according to some of the interviewees, kitchen facilities and a nursing home's principles for care also played a role in selection.

All nursing homes in the study hold an introductory meeting when a new resident arrives at the home. At this meeting, a care plan is drawn up, which includes information about personal needs and preferences. Another feature shared by all of the homes is that each elderly resident has a contact person who is responsible for maintaining contact between the resident, the staff and the relatives. These procedures do not vary across the different types of providers.

However, due to the Christian profile of the nonprofit nursing homes, there are some differences regarding specific activities for the elderly. This includes, for instance, services and other types of activities with religious elements (Interviews, employees, nonprofit nursing homes, 2014-03-01, 2014-03-12).

The managers of the nonprofit care homes also have other types of privileges by virtue of the fact that they run nonprofit facilities. These privileges are primarily related to the larger degree of freedom they experience as nonprofit actors. Although they must live up to municipal quality standards, they have more freedom in the overall running of the nursing home. A short journey from idea to implementation is one of the main strengths mentioned. In one of the nursing homes, the manager was considering buying some sheep for the green areas around the home, and he valued the possibility of being able to do so without having to ask anyone (Interview, manager, nonprofit nursing home, 2014-02-20). However, these kinds of differences are much more evident at the level of the manager than among employees and relatives, who do not experience any significant differences apart from Christian values.

\section{Governing of Nursing Homes}

From the interviews, it is evident that the municipal implementation of national framework legislation promotes similarities among different types of nursing homes with regard to the content of care. In addition to 
these quality standards, the interviews also revealed a strong norm for equality in services: All elderly residents should have the right to the same service standards (Interview, manager, nonprofit, 2014-02-12).

Since 1998, all municipalities have been legally required to formulate quality standards in the field of elderly care. These standards set the framework for the municipal governing of nursing homes. The standards cover both personal and practical care by, for instance, specifying the types of cleaning and other practical help included in and excluded from municipal service, as well as the types of personal care provided and exempted by the municipality (Faaborg-Midtfyn Municipality 2012; Herning Municipality 2008).

Monitoring of nursing homes takes place through regular inspections. For instance, the quality standards in Faaborg-Midtfyn state that unscheduled inspections are conducted once a year at all nursing homes in the municipality. These inspections include discussions with elderly residents, employees and managers regarding the quality of the care provided (Faaborg-Midtfyn Municipality 2012). Municipalities have contracts with nonprofit nursing homes, and these are used to apply the quality standards across different types of providers. The independent nursing homes are also obliged to provide services in accordance with municipal decisions in the field (LBK 897).

In the municipalities examined here, there is a high degree of satisfaction with collaboration with nonprofit nursing homes. In Faaborg-Midtfyn, the head of the nonprofit nursing home is invited to the same leadership seminars that heads of public care homes attend. In Herning, the municipality has more informal relations with the nonprofit nursing homes; but, according to the head of the elderly care administration, relations are very positive. For instance, they are offered the same courses as public nursing homes:

If we have something special to offer - for instance, a seminar on dementia

- the nonprofit nursing homes are also invited. They are not kept outside

- not at all. (Interview, head manager, administration, 2013-12-18).

The manager of the nonprofit nursing home in this study reaffirmed the positive relationship with the municipality (Interview, site manager, nonprofit, 2014-02-12). 
Although the independent nursing homes have not been investigated in detail in this study, they are mentioned repeatedly in interviews with the municipal actors. There are some differences between the independent nursing homes and other types. The independent homes are run on a freer basis, and the ability of local authorities to steer them is very limited (For a further discussion, see Chap. 3). This is evident in the case of Herning. The municipality decided to cancel its contract with two nonprofit nursing homes as part of a larger restructuring, which also included the establishment of new nursing homes in other parts of the municipality. Rather than close, the nonprofit nursing homes decided to continue delivering their services as independent nursing homes. As a result, the municipalities still shoulder the financial costs of these homes, but have no direct influence on them, apart from enforcing quality standards. This is also reflected in an interview with the manager of one of the nonprofit nursing homes, who has a high degree of freedom in the running of the facility (Interview, site manager, independent nursing home 2014-03-03).

While there is general support for the principle of freedom of choice, the establishment of independent nursing homes is considered problematic by municipal actors because of the financial pressures they create. Nonetheless, good relations are still maintained between the municipalities and the independent nursing homes, according to the head manager of the elderly care administration (Interview, head manager, administration, 2013-12-18; Interview, site manager, independent nursing home, 2014-03-03).

Thus, in Denmark, municipalities have the ability to directly steer nursing homes through contracts when they are traditional nonprofit nursing homes. Municipalities always have the right to cancel a contract if, for example, the service provision is not satisfactory or the municipality wants to restructure the field of providers. However, the ability of the municipality to steer nursing homes was significantly reduced with the introduction of the option to operate independent nursing homes in 2007. Today, nonprofit nursing homes can change their status to independent nursing homes if their municipal contract is cancelled. The municipal steering possibilities are very limited when it comes to independent nursing homes. 
Evidence from the Danish case shows that there are no major differences between public and nonprofit nursing homes when it comes to the specific content of care. ${ }^{6}$ This is due to statutory municipal quality standards, which are applied to both public and nonprofit providers. Municipalities can directly steer nursing homes through the use of contracts with traditional nonprofit facilities, which municipalities always have the right to cancel. However, their steering powers have been significantly limited as a result of the relatively new possibility of establishing independent nursing homes. On the whole, the differences between public and nonprofit providers are mainly value-based. However, nonprofit leaders also experience a larger degree of freedom to make local decisions at their nursing homes.

\section{Welfare Providers from Different Sectors-A Comparison}

Based on the results of the empirical investigation, it is evident that the welfare mix of different providers within the field of elderly care has not resulted in greater variety in the content of care. Whether nursing homes are run by public, nonprofit or for-profit organisations, the services they provide are generally the same. This conclusion can be drawn based on interviews with site managers about the content of care and the existence of distinct profiles for their operations. The empirical findings are also supported by the fact that surveys and interviews with relatives and nursing home residents do not point to any major differences among types of nursing homes. However, several minor differences can be noted; for example, a religious profile or the existence of specially trained staff to care for residents suffering from dementia. Nevertheless, differences like these do not seem to have any major impact on the types of services provided.

In all three countries, similarities cannot be explained in any significant way by regulation through national law. For instance, in Sweden,the national law creates a framework that gives the municipalities a great deal of power to make decisions on their own. Following a Scandinavian 
tradition of strong municipal self-rule, the situation is similar in Denmark and Norway. Rather, similarities can be explained by a high degree of local steering that takes several forms.

One of them, which can be regarded as an important underlying condition, is that there are only a limited number of rooms at each nursing home and a queuing system is thus administered by the municipality. This creates a problem for implementing a system of free choice in practice, as there might not be a room available at the chosen nursing home. One can, of course, wait for a room to become available, but considering the physical condition of the elderly, this is not as easy as it sounds.

Another form of steering is the use of quality indicators that are spelled out in contracts between the municipal administration and the nursing home. According to different categories of respondents who were interviewed, the contracts are very detailed, leaving site managers with limited room to manoeuvre regarding the content of the services provided. Quality indicators and contracts are used by municipal administrations regardless of whether nursing homes are run by public or private providers.

Another important tool for municipal steering is the evaluation of nursing homes. Such evaluations assess whether nursing homes are performing their work in accordance with quality indicators. If they are not, contracts can be terminated by the local administration. One part of municipal evaluations is the user survey. These surveys are sent to those receiving care as well as their relatives, and they ask questions about the overall performance of the nursing homes. The surveys can also influence the decision of the municipal administration to extend or terminate its contract with the provider. Another component of the evaluation process is inspection (i.e. site visits), which can be both announced and unannounced.

In sum, the level of administrative governance of nursing homes exercised by municipalities is 'high' regardless of the welfare provider. Denmark represents an exception to this overall pattern insofar as nonprofit providers can apply for status as 'independent nursing homes'. The broader implications of these research findings are considered below. 


\section{Conclusions}

Scandinavian welfare states are currently being reorganised with the market as a model. The pace at which this development is occurring differs among the countries, with Sweden experiencing the most far-reaching changes. There are different rationales driving the development towards marketisation. One of the most common reasons is that the establishment of a market with different providers allows citizens to choose the 'best' alternative in terms of quality. By letting citizens choose, the government is steering the quality of welfare provision through the use of an 'invisible hand'. Simply put, only those welfare providers who can offer services with a sufficient level of quality to attract customers are able to survive in the long run. However, improving quality is not the only motive; another motive is the desire to strengthen user autonomy and enable citizens to choose among a variety of options depending on their own desires and needs.

If citizens are to have alternatives to choose from, then there obviously must be differences among service providers. Hence, it should matter whether the providers are public or private (nonprofit or for-profit). To make this possible, one might expect that there would be less local government steering of service providers. Whether this is actually the case is an empirical question, and little is known about the content and degree of local government steering. It is also possible that there are other reasons behind the development towards marketisation in the welfare field considered here, namely, nursing homes for the elderly.

Accordingly, the purpose of this chapter was to describe and analyse local government steering and how it affects the profile of nursing homes in six municipalities in Sweden, Norway and Denmark. The results of the empirical investigation show that the welfare mix within nursing homes for the elderly has not, to any great extent, resulted in distinct profiles of service provision. The explanation is found in the existence of a high degree of steering by municipalities at the local level, as has been discussed in the previous section.

These findings suggest that the discourse on 'active citizenship' and 'choice' discussed in the first chapter of this book is relevant to consider 
here only to a limited extent. Clearly, the rationale behind the development towards marketisation of nursing homes for the elderly is not foremost about creating a market in which citizens can choose among different alternatives.

Another interpretation of the underlying rationale is that it is about making it possible for the municipal administration to 'benchmark'. By contracting out, the municipality's administration gets a more comprehensive understanding of the costs of running a nursing home. This information can then be used to improve the efficiency of the services performed by the public provider. Following this alternative rationale, there is no need to allow for greater variation among service providers. It is foremost a question of facilities providing a particular service, one that is defined in advance by the municipal administration in the most efficient way.

Another interpretation of our findings is that the similarity in welfare provision across providers is an expression of a central principle of the Scandinavian welfare model-i.e. equality of welfare provision. According to this principle, every citizen is entitled to receive the same welfare content, regardless of place of residence or social stratum. Seen from this perspective, it comes as no surprise that quality indicators and contracts governing nursing homes for the elderly are the same with regard to content of care, regardless of whether the provider is public, for-profit or nonprofit. Simply put, they are important tools for ensuring the preservation of the principle of equality of welfare provision, even in the context of marketisation.

Although this study provides limited evidence of variation in the content of service provision, there is some evidence that things are about to change. In Denmark, nursing homes can apply for the status of 'independent nursing home'. In Sweden, the Freedom of Choice Act (LOV) has mainly been applied to home care services. However, the act can also be applied to nursing homes, and this has actually happened in some municipalities, which implies that a different routine of contracting out is being implemented. The consequences of these relatively new legislative acts must be investigated more closely. In the long run, in these two countries, we might see a development towards less local government steering and more distinct profiles among nursing homes. 
Another topic for further research is the content of contracts and their development. A nursing home is often contracted out for a limited time period. At the end of that period, a new process is initiated in which municipal administrators reformulate old contracts and give them new content. In this process, one would expect that an element of policy learning would take place, i.e. participants would learn through past experiences of the implementation of policy. Whether this learning suggests that more or less detailed regulation is desirable remains to be seen. In several of the interviews, today's detailed regulations were openly questioned by both politicians and civil servants on the grounds that they are counterproductive because they fail to promote efficient solutions.

An additional question for further research concerns the role played by nonprofit organisations in a marketised welfare environment. There is a commonly held belief that nonprofit providers are better able to tailor their services to the particular needs of the elderly, i.e. they can offer a more distinct profile of services. However, the empirical investigation presented here provides little evidence that this is actually taking place. It would be interesting to determine how governance carried out by administrators in municipalities actually restricts how nonprofit providers conduct their operations. What is the potential for services provided by nonprofit providers and how is this potential restricted by local government steering?

As evident from this chapter, the Scandinavian model shows signs of divergence in light of the different speeds at which marketisation has taken place in the different countries. In addition, there are signs of divergence with respect to the role played by nonprofit providers, from their marginal role in Sweden to their more pronounced role in Denmark and Norway. However, this particular difference has been evident for a long time and has little to do with recent developments.

Although there are differences among Sweden, Norway and Denmark, it is still relevant to speak of a Scandinavian model within the field of care for the elderly. The main argument for this is that one of its chief characteristics, equality of welfare provision, is still very much alive at the local level. It is this particular value, expressed by some of the civil servants in the interviews, which constitutes one explanation as to why local governing of different welfare providers is very much the same, 
regardless of whether the provider is a municipal actor or a private one. There are also similar routines for elderly care; for example, implementation plans for each nursing home resident are developed in dialogue with the elderly person and his or her relatives. Besides this, the cornerstones of the Scandinavian model still exist-i.e. publicly financed care for the elderly, accessible to all citizens who need it.

\section{Notes}

1. In this chapter, the use of phrases such as 'content of service provision' refers to the content of care at nursing homes. In turn, content of care refers to various aspects of the activities taking place at the nursing homes; for example, medical care, cultural activities and physical activities such as walks.

2. In some countries, interviews have also been conducted with employees and elderly people living at the nursing homes or their relatives.

3. For a more elaborated definition of an 'independent nursing home', see Chap. 3 by Segaard and Saglie.

4. The figure for 2016 was calculated from statistics presented by the National Board of Health and Welfare (2017). In these statistics, there are municipalities with only a limited number of beds, one or two, which are run by a private operator. This may indicate that beds are purchased by another municipality, which, in turn, has decided to contract out their services. Hence, municipalities with less than five beds, run by a private operator, have not been included in the total number of 93 municipalities.

5. This is in accordance with a national regulation issued by the National Board of Health and Welfare (SOFS 2014:5). The regulation applies to all providers of elderly care regardless of being public or private.

6. For a similar conclusion regarding the Danish case, see Hjelmar et al. 2016.

\section{References}

Almqvist, Robert. 2001. 'Management by contract': A study of programmatic and technological aspects. Public Administration 79 (3): 689-706.

Anttonen, Anneli. 2002. Universalism and social policy: a Nordic-feminist revaluation. NORA 10 (2): 71-80. 
Ascoli, Ugo, and Costanzo Ranci. 2002. Dilemmas of the welfare mix: the new structure of welfare in an era of privatization. New York: Kluwer Academic. Béland, Daniel, Paula Blomqvist, Jørgen Goul Andersen, Joakim Palme, and Alex Waddan. 2014. The Universal Decline of Universality? Social Policy Change in Canada, Denmark, Sweden and the UK. Social Policy \& Administration 48 (7): 739-756.

Bergman, Torbjörn, and Kaare Strøm. 2011. Nordic Europe in Comparative Perspective. In The Madisonian turn: political parties and parliamentary democracy in Nordic Europe, eds. Torbjörn Bergman, and Kaare Strøm. Ann Arbor: University of Michigan Press.

Bertelsen, Tilde Marie, and Tine Rostgaard. 2013. Marketisation in eldercare in Denmark: free choice and the quest for quality and efficiency. In Marketisation in Nordic eldercare: a research report on legislation, oversight, extent and consequences, eds. Gabrielle Meagher, and Marta Szebehely. Stockholm: Department of Social Work, Stockholm University.

Blomqvist, Paula. 2004. The choice revolution: Privatization of Swedish welfare services in the 1990s. Social Policy \& Administration 38 (2): 139-155.

Blomqvist, Paula, and Bo Rothstein. 2000. Välfärdsstatens nya ansikte: demokrati och marknadsreformer inom den offentliga sektorn. Stockholm: Agora.

Boston, Jonathan. 2011. Basic NPM Ideas and their Development. In The Ashgate Research Companion to New Public Management, eds. Tom Christensen, and Per Laegreid. Farnham: Ashgate.

Burau, Viola, and Signy Irene Vabo. 2011. Shifts in Nordic welfare governance: introduction and outlook. International Journal of Sociology and Social Policy $31(3 / 4): 140-147$.

Dahl, Hanne Marlene. 2009. NPM, Disciplining Care and Struggles about Recognition. Critical Social Policy 29 (4): 634-654.

Dahl, Hanne Marlene, and Bente Rasmussen. 2012. Paradoxes in Elderly Care: The Nordic Model. In Elderly Care in Transition: Management, Meaning and Identity at Work. A Scandinavian Perspective, eds. Annette Kamp, and Helge Hvid. Copenhagen: Copenhagen Business School Press.

Dahler-Larsen, Elizabeth, et al. 2015. Eldreomsorg $i$ Norden. Stockholm: Nordens Välfärdscenter.

Dølvik, Jon Erik, Tone Fløtten, Jon M. Hippe, and Bård Jordfald. 2015. The Nordic model towards 2030: A new chapter? Fafo report 2015:07. Oslo: Fafo. Dunleavy, Patric, and Christopher Hood. 1994. From Public-administration to New Public Management. Public Money \& Management 14 (3): 9-16. 
Einhorn, Eric S., and John Logue. 2010. Can Welfare States Be Sustained in a Global Economy? Lessons from Scandinavia. Political Science Quarterly 125 (1): 1-29.

Elinder, Mikael, and Henrik Jordahl. 2013. Kontrakt, kostnader och kvalitet. In Välfärdstjänster i privat regi: framväxt och drivkrafter, ed. Henrik Jordahl. Stockholm: SNS Förlag.

Erlandsson, Sara, et al. 2013. Marketing trends in Swedish eldercare: competition, choice and calls for stricter regulation. In Marketisation in Nordic eldercare: a research report on legislation, oversight, extent and consequences, eds. Gabrielle Meagher, and Marta Szebehely. Stockholm: Department of Social Work, Stockholm University.

Esping-Andersen, Gøsta. 1990. The three worlds of welfare capitalism. Cambridge: Polity.

Faaborg-Midtfyn Kommune. 2012. Pleje og Omsorg, Kvalitetsstandarder 2012.

Feltenius, David, and Jessika Wide. 2015. Deltagardemokrati eller affärsangelägenhet? Om kollektivt deltagande i en marknadiserad äldreomsorg. Statsvetenskaplig tidskrift 117 (4): 587-615.

Ferlie, Ewan. 1996. The new public management in action. Oxford: Oxford University Press.

Gjevjon, Edith Roth, and Tor Inge Romøren. 2010. Vedtak om sykehjemsplasshvor høye er tersklene?. Gjøvik: Senter for omsorgsforskning.

Gustafsson, Agne. 1999. Kommunal självstyrelse: kommuner och landsting i det politiska systemet. Stockholm: SNS Förlag.

Hartman, Laura. 2011. Inledning. In Konkurrensens konsekvenser. Vad händer med svensk välfärd?, ed. Laura Hartman. Stockholm: SNS Förlag.

Haugen, Per Kristian, and Knut Engedal. 2005. Demens. Fakta og utfordringer, en larebok. Oslo: Aldring og helse.

Hermansen, Åsmund, and Heidi Gautun. 2011. Eldreomsorg under press. FAFO: Kommunenes helse- og omsorgstilbud til eldre. Oslo.

Herning kommune. 2008. Generelt tillæg til kvalitetsstandarder - praktisk hjælp. personlig pleje og træning.

Hirschman, Albert O. 1970. Exit, voice, and loyalty: responses to decline in firms, organizations, and states. Cambridge, MA.: Harvard University Press.

Hjemmehjælpskommisionen. 2013. Fremtidens hjemmehjalp - aldres ressourcer $i$ centrum for en sammenhangende indsats. København: Social - og Integrationsministeriet. 
Hjelmar, Ulf, et al. 2016. Kvalitet på offentlige og private plejecentre i Danmark. Forskningsprojektet "Dokumentation af effekter ved konkurrenceudsættelse af offentlige opgaver”. Del-rapport 6. Roskilde: Roskilde Universitet.

Hood, Christopher. 1991. A public management for all seasons. Public Administration 69 (1): 3-19.

Jordahl, Henrik, and Richard Öhrvall. 2013. Nationella reformer och lokala initiativ. In Välfärdstjänster i privat regi: framväxt och drivkrafter, ed. Henrik Jordahl. SNS Förlag: Stockholm.

Kamp, Annette, and Helge Hvid. 2012. Elderly care in transition: management, meaning and identity at work: A Scandinavian perspective. Frederiksberg: Copenhagen Business School Press.

LBK 897, Law of independent nursing homes (LBK nr 897 af 17/08/2011).

Le Grand, Julian. 2007. The other invisible hand: delivering public services through choice and competition. Princeton: Princeton University Press.

Lindbom, Anders. 2001. Dismantling the social democratic welfare model? Has the Swedish welfare state lost its defining characteristics? Scandinavian Political Studies 24 (3): 171-193.

Loughlin, John, Frank Hendriks, and Anders Lidström. 2011. Introduction. In The Oxford handbook of local and regional democracy in Europe, eds. John Loughlin, Frank Hendriks, and Anders Lidström. Oxford: Oxford University Press.

Mariani, Laura, and Dario Cavenago. 2013. Redesigning welfare services for policies effectiveness: The non-profit organizations (NPOs) perspective. Public Management Review 15 (7): 1011-1039.

Osborne, Stephen P. 1998. Voluntary organizations and innovation in public services. London: Routledge.

Osborne, Stephen P. 2010. Delivering Public Services: Time for a new theory? Public Management Review 12 (1): 1-10.

Östersunds kommun. 2006. Plan för vård och omsorg: Inriktningsmål och strategier. Östersund: Östersunds kommun.

Östersunds kommun. 2013-06-13. Kommentarer - brukarenkät [A non-published report].

Östersunds kommun. 2013-09-16. Sammanställning av synpunkter från anhöriga. [A non-published report].

Östersunds kommun. 2014. Din rätt till trygghet och ett värdigt liv. Östersund: Vård- och omsorgsförvaltningen. 
Petersen, Ole Helby, and Ulf Hjelmar. 2013. Marketization of welfare services in Scandinavia: A review of Swedish and Danish experiences. Scandinavian Journal of Public Administrations 17 (4): 3-20.

Pierre, Jon. 1995. The marketization of the state: Citizens, consumers and the emergence of the public market. In Governance in a changing environment, ed. Guy B. Peters, and Donald J. Savoie. Ottawa: Canadian Centre for Management Development.

Pierson, Paul. 1994. Dismantling the welfare state? Reagan, Thatcher and the politics of retrenchment. Cambridge: Cambridge University Press.

Pollitt, Christopher. 1995. Justification by work or faith? Evaluation 1 (2): 133-154.

Rambøll. 2012. Evaluering af lov om friplejeboliger. Rambøll Management (udarbejdet for Ministeriet for By, Bolig og Landdistrikter): København.

Salamon, Lester M., and A.J. Abramson. 1982. The Nonprofit Sector. In The Reagan Experiment: An Examination of Economic and Social Policies Under the Reagan Administration, eds. John L. Palmer, and Isabel V. Sawhill. Washington D.C.: The Urban Institute Press.

Salamon, Lester M. 1987. Of Market Failure, Voluntary Failure, and Third-Party Government: Toward a Theory of Government-Nonprofit Relations in the Modern Welfare State. Nonprofit and Voluntary Sector Quarterly 16 (1-2): 29-49.

Salamon, Lester M. 1993. The Marketization of Welfare: Changing Nonprofit and Forprofit Roles in the American Welfare-state. Social Service Review 67 (1): 16-39.

Sivesind, Karl Henrik. 2016. Endring av fordelningen mellom ideelle, kommersielle og offentlige velferdstjenster i Skandinavia. In Mot en ny skandinavisk velferdsmodell? Konsekvenser av ideell, kommersiell og offentlig tjenesteyting for aktivt medborgerskap, ed. Karl Henrik Sivesind. Oslo: Institutt for samfunnsforskning.

Socialstyrelsen. 2004. Konkurrensutsättningen inom äldreomsorgen. Stockholm: Socialstyrelsen.

Socialstyrelsen. 2017. Statistik om äldre och personer med funktionsnedsättning efter regiform 2016. Socialstyrelsen: Stencil med tillhörande datafil. Stockholm.

Sollentuna kommun., 2012. Äldreomsorg: Kvalitetsbarometern. Sollentuna: Sollentuna kommun. 
SOSFS. (2014:5). Dokumentation i verksamhet som bedrivs med stöd av SoL, LVU, LVM \& LS. Socialstyrelsens författningssamling. Socialstyrelsen: Stockholm.

Stolt, Ragnar, and Ulrika Winblad. 2009. Mechanisms behind privatization: A case study of private growth in Swedish elderly care. Social Science \& Medicine 68 (5): 903-911.

Szebehely, Marta. 2011. Insatser för äldre och funktionshindrade i privat regi. Stockholm: SNS Förlag.

Traetteberg, Håkon Dalby, and Karl Henrik Sivesind. 2015. Ideelle organisasjoners saertrekk og merverdi på helse- og omsorgsfeltet. Oslo: Senter for forskning på sivilsamfunn \& frivillig sektor.

Vabø, Mia. 2007. Organisering for velferd. Unipub: Hjemmetjensten i en styrningsideologisk brytningstid. Oslo.

Walsh, Kieron. 1995. Public services and market mechanisms: competition, contracting and the new public management. Basingstoke: Macmillan.

Weisbrod, Burton. 1977. The voluntary nonprofit sector: an economic analysis. Lexington, MA.: Heath.

Weisbrod, Burton Allen. 1988. The nonprofit economy. Cambridge, Mass.: Harvard University Press.

Vård- och omsorgsnämnden. 2013. Äldreplan. Sollentuna: Sollentuna kommun.

\section{Author Biography}

David Feltenius is Associate Professor at the Department of Political Science in Umeå, Sweden. In addition to studies on marketisation and the welfare state, his research focuses on central-local government relations and territorial politics. His recent publications include a chapter on subnational government in a multilevel perspective in the Oxford Handbook of Swedish Politics, as well as an article on parties and the politics of territorial reform published in Scandinavian Political Studies. Feltenius is currently working in a research project on inter-agency collaboration financed by the Swedish Research Council. 
Open Access This chapter is licensed under the terms of the Creative Commons Attribution 4.0 International License (http://creativecommons.org/licenses/by/ $4.0 /$ ), which permits use, sharing, adaptation, distribution and reproduction in any medium or format, as long as you give appropriate credit to the original author(s) and the source, provide a link to the Creative Commons license and indicate if changes were made.

The images or other third party material in this chapter are included in the chapter's Creative Commons license, unless indicated otherwise in a credit line to the material. If material is not included in the chapter's Creative Commons license and your intended use is not permitted by statutory regulation or exceeds the permitted use, you will need to obtain permission directly from the copyright holder.

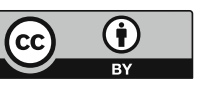

